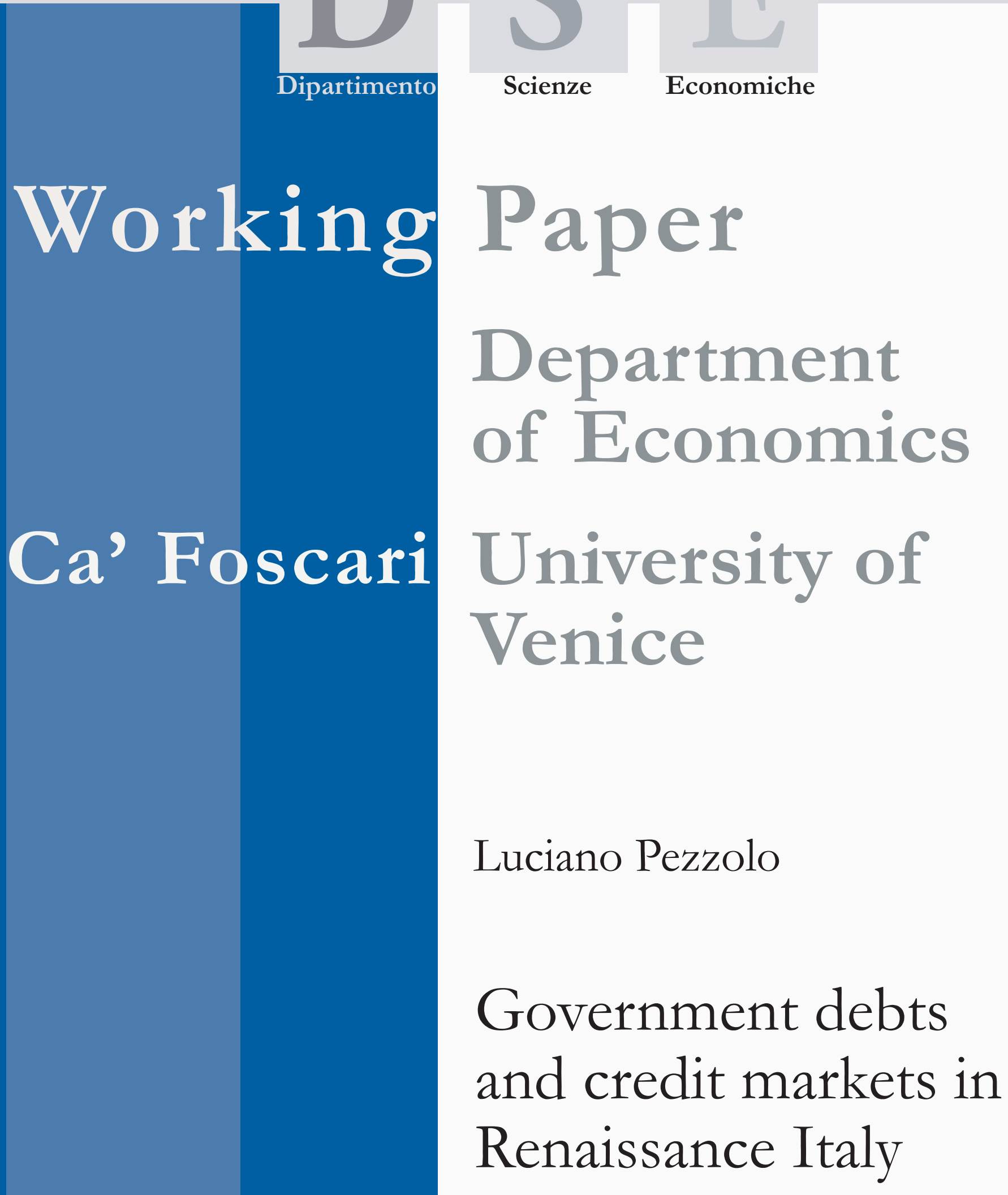




\title{
Government debts and credit markets in Renaissance Italy
}

\author{
Luciano Pezzolo \\ Università Ca' Foscari di Venezia \\ and School for Advanced Studies in Venice Foundation
}

First Draft: May 20, 2007

\begin{abstract}
At first sight a marked difference turns out among the Italian governments of early Renaissance: the means of financing their deficit. There are, on the one hand, communal cities and republics, raising money from citizens through the system of forced or voluntary loans; there are, on the other, princes and lords who exploit services of bankers and merchants. These two different systems of borrowing bring about significant financial and political aspects. In this paper I will examine the main features characterizing the two mechanisms of indebtedness and the implications concerning the emergence of a true financial market connected with state bonds.
\end{abstract}

\section{Keywords}

Public debts, Renaissance Italy, financial markets, financial institutions

JEL Codes

N2, N23

Address for correspondence:

Luciano Pezzolo

Department of Economics

Ca' Foscari University of Venice

Cannaregio 873, Fondamenta S.Giobbe

30121 Venezia - Italy

Phone: (++39) 0412349150

Fax: (++39) 0412349176

e-mail: pezzolo@unive.it

This Working Paper is published under the auspices of the Department of Economics of the Ca' Foscari University of Venice. Opinions expressed herein are those of the authors and not those of the Department. The Working Paper series is designed to divulge preliminary or incomplete work, circulated to favour discussion and comments. Citation of this paper should consider its provisional character.

$\begin{aligned} \begin{array}{r}\text { The Working Paper Series } \\ \text { is availble only on line }\end{array} & \begin{array}{l}\text { Department of Economics } \\ \text { Ca' Foscari University of Venice }\end{array} \\ \text { (www.dse.unive.it/pubblicazioni) } & \text { Cannaregio 873, Fondamenta San Giobbe } \\ \text { For editorial correspondence, please contact: } & \text { 30121 Venice Italy } \\ \text { wp.dse@unive.it } & \text { Fax: ++39 041 2349210 }\end{aligned}$




\section{The financing system of governments}

At first sight a marked difference turns out among the Italian governments of early Renaissance: the means of financing their deficit. There are, on the one hand, communal cities and republics, raising money from citizens through the system of forced or voluntary loans; there are, on the other, princes and lords who exploit services of bankers and merchants. These two different systems of borrowing bring about significant financial and political aspects. In this paper I will examine the main features characterizing the two mechanisms of indebtedness and the implications concerning the emergence of a true financial market connected with state bonds.

As far as we know, in the cities the first loans were on a voluntary basis. Pressed by urgent - usually military - needs, the commune requested the wealthiest citizens to lend a given sum and committed itself in order to pay it back in short time. The social area of lenders was composed of merchants, bankers, Jews and sometimes foreigners. The government usually granted tax proceeds or domain revenues as guaranty. This practice took place beginning from the twelfth century, as the cities seized control of taxing rights from feudal lords and ecclesiastical institutions. ${ }^{1}$

The availability of loans, though, was not adequate for the growing financial needs of communes, engaged in an expensive territorial expansion. Governments thus requested both forced and voluntary loans. The system relied on fiscal documents (estimi and catasti) that assessed for all citizens the amount of wealth or income. According to these documents, the government assigned the amount each citizen had to lend. In this case loans usually were short term and with a modest interest rate. This system considerably enlarged the social area of lenders; all the citizens, apart from the poorest ranks, were requested to put money into the commune's coffers. Likewise, the Jewish community was obliged to lend to the government. Although the government debt was characterized by the participation of city dwellers, it is nevertheless worth noting that in some cases subject communities were involved in the system. In 1287 in Siena, for example, the presta generalis (general loan) was imposed on both the capital city and the rural communities. In 1371, the same occurred in Lucca. During the second half of the fifteenth century, also Venice, albeit seldom, collected forced loans from the subject cities. Like the voluntary loans, the forced loans were conceived as short-term loans, guaranteed on fiscal revenues that also assured interest payments. ${ }^{2}$

\footnotetext{
${ }^{1}$ Gino Luzzatto, Le origini dell'organizzazione finanziaria dei comuni italiani (Urbino: QuattroVenti, 1990), pp. $88 \mathrm{ff}$.

I wish to thank Julius Kirshner and Bepi Tattara, who read an earlier version of this paper providing me with useful comments.

${ }^{2}$ See, for example, William Bowsky, Le finanze del comune di Siena 1287-1355 (Firenze: La Nuova Italia, 1975), pp. 449 ff. (Appendix 12); Duccio Balestracci, La zappa e la retorica. Memorie familiari di un contadino toscano del Quattrocento (Siena: Salimbeni, 1984), pp. 144, 147-48; Christine Meek, Lucca 1369-1400. Politics and Society in an early Renaissance City-State (Oxford:
} 
As far as the signorie, the papal state and the kingdom of Naples are concerned, the picture is very different. The mechanism of borrowing first relied on the money provided more or less freely from merchants, bankers, courtesans, and foreigners. As a consequence, one might paradoxically argue that a primary market existed in the princely states, whereas instead a 'public' debt similar to that of the city-states did not exist. It was a very peculiar primary market, however, which should be defined more properly as a personal market. The lenders to princes usually were merchants and bankers whose business in the country were conspicuous. Thus, no wonder to see the Strozzi bank heavily involved in managing state finance in Aragonese Naples; or the Medici, lending to the duke of Milan. Loans to the lord and commercial activities intertwined, constituting a mechanism extremely advantageous to lenders as long as the debtor kept his promises. ${ }^{3}$ Along with these people, who can be considered credit specialists, there were around the prince also nobles and officers, who wished to get or to enhance a political role through lending activity. They willingly lent, sometimes even at no interest, counting on princely benevolence in order to get privileges, offices and advantages, as in late mediaeval Turin. ${ }^{4}$ Such a mechanism in some ways recalls the cronyism evocated by Hilton Root with regard to ancient regime France. ${ }^{5}$ The king stood at the centre of a system of relations that, if well exploited, allowed to achieve enormous political and economic advantages, but at the same time encouraged a rent seeking behaviour. This system, however, called for high costs, due to the great uncertainty pervading the relations between creditors and king. The latter, in fact, was not bound to any rule and could repudiate his commitments almost with no consequences. This sharp asymmetry of course brought about costly loans. Therefore it was usual that loans for princes were much dearer than those obtained by urban governments. In the mid-fifteenth century, the Aragonese crown in Naples, for example, paid interest rate as high as $40 \%$, while in Florence interest on short-term loans usually did not exceed 12$14 \%{ }^{6}$ This spread witnessed, among other things, the different degree of risk in government borrowing.

Oxford University Press, 1978), p. 48; Luciano Pezzolo, Il fisco dei veneziani. Finanza pubblica ed economia tra XV e XVII secolo (Verona: Cierre, 2003), pp. 21-22.

${ }^{3}$ Mario Del Treppo, 'Il re e il banchiere. Strumenti e processi di razionalizzazione dello stato aragonese di Napoli', in G. Rossetti (ed.), Spazio, società, potere nell'Italia dei Comuni (Napoli: Liguori, 1986), pp. 269. See also Alan Ryder, 'Cloth and credit: Aragonese war finance in the mid fifteenth century’, War and society, 2 (1984), pp. 1-21.

${ }^{4}$ Alessandro Barbero, Un'oligarchia urbana. Politica ed economia a Torino fra tre e quattrocento (Roma: Viella, 1995), pp. 217-18, $231 \mathrm{ff}$.

${ }^{5}$ Hilton L. Root, The Fountain of Privilege. Political Foundations of Markets in Old Regime France and England (Berkeley: University of California press, 1994).

${ }^{6}$ Riley, 'Cloth and credit', p. 13; Richard Goldtwaithe, 'Lorenzo Morelli, Ufficiale del Monte, 148488: interessi privati e cariche pubbliche nella Firenze laurenziana', Archivio Storico Italiano, 154 (1996), pp. 613, 617, 630. 


\section{Funding debt and the emergence of the financial market}

Beginning from the second half of the thirteenth century, some urban governments recognized it was impossible to return the principal being borrowed, and decided to change some elements of their debt. Short-term loans were actually transformed in long-term loans; the receipts of some tax revenues were assigned for paying interest (5\% in Florence and Venice, 7\% in Genoa, from two to six times a year); all the series were unified in a Monte (or compera, in Genoa) and managed by a specific office; furthermore, negotiability of state credits was allowed. Venice in 1262 and Genoa in 1274 opened the way; by the mid-fourteenth century they were followed by Florence, Pisa, Siena, and Lucca. ${ }^{7}$ It was not indeed a true consolidation, since reimbursements were still undertaken; but undoubtedly government creditors abandoned their hope to get their money back. The institutionalisation of the debt also brought about an important process of socialisation of the debt. By means of middlemen and speculators bonds circulated throughout almost all social environments, from the great merchants to the humble artisans. It is also worth noting that the resort to forced loans pushed governments to improve the tax records. Citizens thus became true lender-taxpayers rather than lender-investors. It is useful to stress this aspect, which sheds a particular light on the indebtedness mechanism of Italian renaissance cities. A structural change actually occurred. As long as state finance was not under severe and extended pressure, the system represented a 'moneylender's paradise'. ${ }^{8}$ Principal was paid back in relative short time and interest also was paid regularly. But growing and endless expenses provoked huge holes in the budget: thus indebtedness became a regular tool, which led almost naturally to funding. The pace of indebtedness of the main cities can be seen in Table 1, showing the performances of Italian cities in comparison with data concerning the European great powers, the latter available only for the mid-seventeenth century.

Table 1. Estimate of per capita indebtedness 1350-1650

(Kg of silver)

Venice Genoa Florence Holland Castile France

$\begin{array}{lcccccc}1350 & 0.2 & & 0.2 & & & \\ 1400 & 1.7 & 2.1 & 2.8 & & & \\ 1450 & & 3 & & & & \\ 1500 & 4.1 & 2.7 & 3.0 & & & \\ 1600 & 0.1 & 5.4 & & & & \\ 1650 & 1.7 & 3.6 & 0.5 & 1.7 & 0.6 & 0.4\end{array}$

Source: Author's database. The sources of these data will be presented more extensively in a forthcoming monograph. For 1650, James Macdonald, A free nation deep in debt. The financial roots of democracy (New York: Farrar, Straus and Giroux, 2003), p. 152.

\footnotetext{
${ }^{7}$ For sake of brevity, see especially Maria Ginatempo, Prima del debito. Finanziamento della spesa pubblica e gestione del deficit nelle grandi città toscane (1200-1350 ca.) (Firenze: Olschki, 2001).

${ }^{8}$ Lauro Martines, Power and Imagination. City-States in Renaissance Italy (New York: Vintage Books, 1979), p. 175.
} 
These data confirm how the political and above all the economic power of major Italian city-states relied on the exploitation of capital-intensive resources, according to the well-known definition of Charles Tilly. ${ }^{9}$ It is also worth noting that the amount of indebtedness considerably increased, despite the demographic crisis of the mid-fourteenth century, due to a long period of interstate conflicts. Still, it is surprising that by the midseventeenth century the per capita burden was not lower than the Dutch figure, which represented the most developed area in Europe at that time and furthermore a recent theater of a long and costly war against the Spanish crown. One has however to consider that in Italy the debt was concentrated within the single cities, while in other countries it was spread throughout a wider area.

Undoubtedly the consolidation triggered the development of the secondary market of state credits, yet it did not create it. Credits had sometimes been circulating before consolidation. In the thirteenth century, in Treviso and Vicenza credits were, albeit not often, negotiated; but it is likely that this operation was quite exceptional. ${ }^{10}$ There are Milanese examples of transferring credits of the commune, but these were IOU, which did not seem very popular among citizens. ${ }^{11}$ The secondary market, though, developed as the government demand of loans grew and the institutionalization of the debt took place. ${ }^{12}$ The formation of a wide secondary market made government bankruptcy expectations a matter of public discussion. ${ }^{13}$ A system, on the one hand, based mainly on personal relations between creditors and government allowed the latter to decree a selective suspension of payment; a system, on the other hand, based on a large secondary market presented the government with a few choices and stronger constraints, for a wider public had to be taken into account. This does not mean that urban governments did not make any distinction among creditors. In 1316, as the Venetian government decided to extinguish a part of its debt, creditors of amounts below ten lire were repaid with $70 \%$ of their principal, whereas $80 \%$ was returned to the bondholders of amounts from ten to fifteen lire. In Genoa the partecipes grossiores (most important shareholders) exercised a certain influence on the government's financial

\footnotetext{
${ }^{9}$ Charles Tilly, L'oro e la spada. Capitale, guerra e potere nella formazione degli stati europei 9901990 (Firenze: Ponte alle Grazie, 1991).

${ }^{10}$ Alfredo Michielin e Gian Maria Varanini, 'Nota introduttiva', in Alfredo Michielin (ed.), Mutui e risarcimenti del comune di Treviso (secolo XIII) (Roma: Viella, 2003), pp. LXXVII, LXXX; Franco Scarmoncin (ed.), I documenti del Comune di Bassano dal 1259 al 1295 (Padova: Antenore, 1989).

${ }^{11}$ Paolo Grillo, 'L'introduzione dell'estimo e la politica fiscale del comune di Milano alla metà del secolo XIII (1240-1260)', in Patrizia Mainoni (ed.), Politiche finanziarie e fiscali nell'Italia settentrionale (secoli XIII-XV) (Milano: Unicopli, 2001), pp. 22-23, 35-36; Gino Barbieri, Origini del capitalismo lombardo. Studi e documenti sull'economia milanese del periodo ducale (Milano: Giuffrè, 1961), pp. 15-16, 31-32.

${ }^{12}$ It seems that the backwardness of the financial market in preindustrial China was due above all to the lack of state credit demand: see Jean-Laurent Rosenthal and Bin Wong, 'Another look at credit markets and investment in China and Europe before the industrial revolution', mimeo, 2005. For the French case, Philip T. Hoffman, Gilles Postel-Vinay, Jean-Laurent Rosenthal, Priceless Markets. The Political Economy of Credit in Paris, 1660-1870 (Chicago: University of Chicago Press, 2000).

${ }^{13}$ See Hoffman, Postel-Vinay, Rosenthal, Priceless Markets, p. 289.
} 
policy. ${ }^{14}$ In principalities, however, major financiers - who managed the mechanism of taxation - enjoyed more advantages than small lenders. The former purchased from the latter their devaluated credits and then, counting on their influence at court and the treasury, were more successful in getting back money ${ }^{15}$.

Venice and Genoa present the emergence of a precocious financial market of state credits. Some decades later, Florence followed the example of the two maritime cities, when in 1345 allowed the transferability of rights on Monte bonds in order to face creditors' protest. ${ }^{16}$ As far as the working of market is concerned, some common elements turn out. The bond trade was vivid and involved large sections of the population; middlemen took on an essential role to meet sellers and buyers, fixing the current price and thus leading the market movements; transactions had to be registered at the offices managing the debt.

But differences were significant, indeed. Especially in the fifteenth century, the Florentine government appointed prominent people - bankers and merchants - as Monte officers who were expected to collect short-term loans, mostly from their network of relatives and friends. The principal was to be returned through the receipt of successive forced loans.17 It seems instead that the Genoese and Venetian governments did not use intermediaries between lenders and the treasury. Venetian bankers were called to anticipate money and pay on behalf of the government, but there is no evidence of their involvement in finding lenders.18 It is, however, not surprising that in these two cities there were no influential intermediaries. Particularly in Venice, the need to maintain equilibrium within the patriciate prevented the formation of powerful positions and, at least up to the fifteenth century, the wealth of individuals (and of their families) did not exert that influence that instead was to be found later. In fifteenth-century Venice, the ruling group was still constituted largely of merchants; the assignment to a few of them of the function of fundraisers would have been very risky, both in financial and political terms. In Florence, on the other hand, the ruling group was economically less homogeneous and, mainly

\footnotetext{
${ }^{14}$ Heinrich Sieveking, Studio sulle finanze genovesi nel medioevo e in particolare sulla Casa di S. Giorgio (Genova: Società Ligure di Storia Patria, 1905), vol. 1, p. 206.

${ }^{15}$ Federico Chabod, Storia di Milano nell'età di Carlo V (Torino: Einaudi, 1971), pp. 353-54; and, for a later example, Rosario Villari, La rivolta antispagnola a Napoli. Le origini (1585-1647) (RomaBari: Laterza, 1967), p. 148.

${ }^{16}$ On the misleading use of the term negotiability in the early phase of the Florentine Monte, see the subtle pages of Julius Kirshner, 'Encumbering Private Claims to Public Debt in Renaissance Florence', in Vito Piergiovanni (ed.), The Growth of the Bank as Institution and the Development of Money-Business Law (Berlin: Duncker \& Humblot, 1993), pp. 19-75.

17 Goldthwaite, 'Lorenzo Morelli', pp. 605-33. Sergio Tognetti, Il banco Cambini. Affari e mercati di una compagnia mercantile-bancaria nella Firenze del XV secolo (Firenze: Olschki,1999), pp. 258, 261; Anthony Molho, Florentine Public Finances in the Early Renaissance, 1400-1433 (Cambridge, Mass.: Harvard University Press, 1971), pp. 153, 164, 170,176; Id., 'Lo stato e la finanza pubblica. Un'ipotesi basata sulla storia tardomedievale di Firenze', in Giorgio Chittolini, Anthony Molho and Pierangelo Schiera (eds), Origini dello stato. Processi di formazione statale in Italia fra medioevo e età moderna (Bologna: Il mulino, 1994), pp. 225-80.

${ }^{18}$ Reinhold C. Mueller, The Venetian Money Market. Banks, Panics and Public Debt, 1200-1500 (Baltimore: Johns Hopkins University Press, 1997), pp. 425 sgg.
} 
during the Medici age, was not very concerned with maintaining an apparent egalitarian structure. Likewise, in princely states the lord could count on some individuals to construct close relationships of reciprocal interest that linked the financial needs of the government to merchant lenders' prospect of profit. Personal relations therefore prevailed in principalities, whereas in cities run by oligarchies the debt relied on a sort of impersonal market, where as a rule all creditors enjoyed the same rights and suffered the same damages.

It would, thus, seem reasonable to consider the urban means of indebtedness more dynamic and flexible than those of seigniorial and monarchic regimes, unable to develop financial innovations. This is true, but only partially. Beginning from the mid-fifteenth century, in fact, in both Naples and Rome the government attempted, although cautiously, to promote innovations. Alfonso $\mathrm{V}$, in order to fund the war for the conquest of Naples, not only resorted to usual means (mortgages, bills of exchange) but also sought new ways. The liquidation of consistent loans was scheduled over a quite long period, so transforming short into long-term loans. The royal treasury, moreover, issued certificates of credit guaranteed on tax receipts; such credits could be transferred to creditors of merchants, who in turn had to get money from the treasury. ${ }^{19}$ However, the continuous financial needs of the Aragonese foreign policy did not allow the establishment of the system and the emergence of a broad capital market.

In Rome on the contrary some financial innovations took up a firm feature and represented the base for further developments. Along with the traditional role of bankers, the popes had exploited the venality of offices, but from the pontificate of Sixtus IV (1471-84) the system began to show new characteristics, becoming a true financial device that released the office from any administrative duty. In 1486, for the first time this new charge was sold setting up up the so-called offices of third category. The purchaser of the office was to pay a given amount (the principal) and the government was to pay him a lifeterm 'salary' (the interest). Later it was allowed the transfer of the right to the 'salary' even upon the nominee's death. In 1514, furthermore, the first societas officiurum was founded, that is a company constituted of people willing to invest in lifeterm (vacable) offices, but who individually could not purchase it. ${ }^{20}$ The diffusion of government loans through offices brought about, according to Bauer, the 'democratization of the papal state credit'. ${ }^{21}$ The vacable offices actually enjoyed a large success. By 1520 the selling of third category offices had provided the papal coffers with an amount of 2.5 million ducats. ${ }^{22}$ The success of the vacable

\footnotetext{
${ }^{19}$ Ryder, 'Cloth and credit', pp. 12-13; Alfonso Silvestri, 'Sull'attività bancaria napoletana durante il periodo aragonese', Bollettino dell'Archivio Storico del Banco di Napoli, 6 (1953), pp. 87, 97.

${ }^{20}$ Fausto Piola Caselli, 'Aspetti del debito pubblico nello stato pontificio: gli uffici vacabili', Annali della Facoltà di Scienze Politiche dell'Università di Perugia, 11 (1970-72), pp. 3-74. For the decision to allow the constitution of investors' companies, Walther v. Hofmann, Forschungen zur Geschichte der kurialen Behörden von Schisma bis zur Reformation (Rom: Loescher, 1914), vol. 1, pp. 188-89.

${ }^{21}$ Clemens Bauer, 'Die Epochen der Papstfinanz. Ein Versuch', Historische Zeitschrift, 138 (1928), p. 488.

${ }^{22}$ Felice Litva, 'L’attività finanziaria della Dataria durante il periodo tridentino', Archivum historiae pontificiae, 5 (1967), p. 135. Data on offices of third category sold between the fifteenth and sixteenth century in Piola Caselli, ‘Aspetti', pp. 27, 30-31, 34.
} 
offices over the sixteenth century is witnessed by their growing market price.

Table 2: Prices of offices of third category at Rome, 1514-1590

Constant price index $(1514=100)$

$\begin{array}{llllll}\text { Offices } & 1514 & 1525 & 1531 & 1565 & 1590 \\ \text { Cubicolari } & & & & & \\ \text { Scudieri } & 100 & 120 & 116 & 122 & 196 \\ \text { Collettori } & 100 & 103 & 105 & 151 & 256 \\ \text { Giannizzeri } & 100 & 103 & 95 & 57 & 70 \\ \text { Archivio } & 100 & 94 & 93 & 73 & 89 \\ \text { Presidenti } & 100 & 103 & 102 & 139 & 158 \\ \text { Porzionari } & 100 & 92 & 99 & 108 & 104 \\ & 100 & 94 & 70 & 121 & 121\end{array}$

Sources: Bernhard Schimmelpfennig, 'Der Ämterhandel an der römischen Kurie von Pius II. bis zum Sacco di Roma (1458-1527)', in Ilja Mieck (ed.), Ämterhandel im Spätmittelalter und im 16. Jahrhundert, (Berlin: Colloquium Verlag, 1984), pp. 39-41; Thomas Frenz, Die Kanzlei der Päpste der Hochrenaissance (1471-1527), (Tübingen: Niemeyer, 1986), pp. 204 ff.; Piola Caselli, 'Aspetti', pp. 40, 63-65. The silver content of currency has been used as deflator.

Up to the middle of the century, prices did not significantly grow while later the market received offices warmly. The success of these investments, however, declined as the monti camerali appeared. The monti camerali were true bonds, sold by the Apostolic Chamber, which since the mid-sixteenth century broadly spread out and constituted the pillar of the papal debt up to the arrival of the Napoleonic troops. Over the seventeenth century, however, offices continued to play an important role as a means of credit among individuals. ${ }^{23}$

In the early sixteenth century the interest rate of offices was around $12 \%$, in line with returns in other markets. It is worth noting that the papal choice to sell annuities - as was happening in early-sixteenth century Venice - was against the trend of other cases. In Bâle, for example, the city government gave up resorting to annuities because they proved very expensive. $^{24}$

\footnotetext{
${ }^{23}$ Anna Esposito, 'Note sulle societates officiorum alla corte di Roma nel pontificato di Sisto IV', in Brigitte Flug, Michael Matheus and Andreas Rehberg (eds), Kurie und Region. Festschrift für Brigide Schwarz zum 65. Geburstag (Stuttgart: Steiner, 2005), pp. 197-207; Renata Ago, Economia barocca. Mercato e istituzioni nella Roma del seicento (Roma: Donzelli, 1998), pp. 192-93; Ead., 'Norme e regole: i ceti urbani davanti al notaio', in Disuguaglianze: stratificazione e mobilità sociale nelle popolazioni italiane (dal sec. XIV agli inizi del secolo XX) (Bologna: Cleup, 1997), vol. 2, pp. 540-41. ${ }^{24}$ Hans-Jörg Gilomen, 'La prise de décision en matière d'emprunts dans les villes suisses au XVe siècle', in Marc Boone, Karel Davids and Paul Janssens (eds), Urban public debts. Urban government and the market for annuities in western Europe (14 ${ }^{\text {th }}-18^{\text {th }}$ centuries) (Turnhout: Brepols, 2003), pp. 137, 139.
} 


\section{How the market works}

In the cities, creditors were above all the inhabitants registered in the estimo and, particularly, those assessed above a given threshold of taxable wealth. Lending to the commune was considered a duty as much as servicing the urban militia. The option of borrowing therefore was not, at least initially, criticized; it reflected the choice to limit the use of direct taxation. The continuous resort to forced loans nevertheless raised critics and unrest. It was not an accident that in Florence, during the revolt of the Ciompi, claims of the rebels aimed to abolish loans carrying high interest rate as well as to resort to direct taxation. ${ }^{25}$ In 1339 , during one of the numerous riots that occurred in Genoa, the records of creditors were burnt; and in 1408 the same fate occurred to the first documents of the Casa di San Giorgio. ${ }^{26}$ At the same time, the registers were important as proof of ownership of credits and served to support trust in the Monte, compere, and served to minimize fraud.

In many cases the duty to lend to the city government was, as already said, closely linked to the citizenship right. In the urban world of northern Italy, to be a citizen took on different meanings and involved different categories according to places and periods. ${ }^{27}$ Not all the inhabitants of the city were considered citizens pleno iure, there were cives comitatenses, not to speak of the 'originals', who distinguished themselves from the 'foreigners'. Citizenship created a specific relation between the inhabitants falling in the definition and the ruling elite. It was a sort of contract that was, on the one hand, to protect the citizens from the government's abuses and, on the other hand, to guarantee a wide consent to the fiscal demand of authorities. ${ }^{28}$ It is thus interesting to wonder whether the growing fiscal demand brought about a reconsideration of citizenship within the urban fabric. The authorities' major concern was to identify the taxable citizens, without considering their local status. It was the payment of the taxes instead that actually sustained the legitimacy of applications for citizenship. If to defend homeland, as much with arms as money, was considered as the primary duty of the citizen, then the restless financial needs of the government pushed to widen the urban structure to be provided with some rights.

As far as foreigners are concerned, the statutes generally raised constraints to their purchase of state bonds. They could buy credits only upon the commune's authorization. In Florence, for example, the law did

\footnotetext{
${ }^{25}$ Roberto Barducci, 'Le riforme finanziarie nel tumulto dei Ciompi', in Il Tumulto dei Ciompi; Un momento di storia fiorentina ed europa (Firenze: Olschki, 1981), pp. 95-102.

${ }^{26}$ Sieveking, Studio sulle finanze, p. 126; Steven A. Epstein, Genoa and the Genoese, 958-1528 (Chapel Hill: North Carolina University Press, 1996), pp. 204-5; Giorgio Felloni, 'Introduzione' to Giorgio Felloni (ed.), Inventario dell'Archivio del Banco di San Giorgio (1407-1805) (Roma: Ministero dei Beni Culturali, 1989), vol. 4, 1, p. 18 n. For a similar episode in Bâle, Gilomen, 'La prise de décision', p. 131.

${ }^{27}$ See the remarks of Julius Kirshner, 'Civitas sibi faciat civem: Bartolus of Sassoferrato's doctrine on the making of a citizen', Speculum, 48 (1973), pp. 699-701; as well as Paolo Costa, Civitas. Storia della cittadinanza in Europa (Roma-Bari: Laterza, 1999), vol. 1, pp. 14 sgg.

${ }^{28}$ I'm referring to the model put forward by Jan Luitev van Zanden and Maarten Prak, 'Towards an Economic Interpretation of Citizenship: The Dutch Republic Between Medieval Communes and Modern-States', in European Review of Economic History, 10 (2006), pp. 111-45.
} 
not allow Florentines to sell their credits to foreigners, but in case of need the government called for also foreigners' purses, though with caution. ${ }^{29}$ In 1415 the government opened the door to non-Florentine subscribers, but at the same time raised a tax of $10 \%$ on the amount being purchased. The tax was on the face value, usually much higher than the market price. This rule - sometime made flexible - however did not seem to have limited foreign capital supply. It is interesting to note that the government granted citizenship in order to draw foreign investors, who sometime enjoyed a higher interest rate than the usual one. ${ }^{30}$

Borrowing from foreigners was not a matter to be trifled with. In exchange of an inflow of fresh money there might be the danger to create a too strong connection with the creditor, especially if the latter was a powerful person. In 1446 Florence, not having paid interest to the pope Eugenio IV's Monte credits, had to face a reprisal, which was carried out by seizing goods of Florentine merchants in Rome and even imprisoning the ambassador Bernardino of Antonio de Medici. ${ }^{31}$ It is not surprising, therefore, that in 1470, when the government reduced the interest rate on the Monte credits, the king of Portugal and several Genoese were excluded, just to avoid the threat of reprisals. ${ }^{32}$

The institutionalization of the state debt brought about an important process of socialization of debt. The move from voluntary loans, addressed to a restricted group of people, to forced loans based on tax records and estimi represented a true innovation, not only in financial but also political and to some extent social terms. ${ }^{33}$ Almost all the social groups in the main central-northern cities held or dealt with government bonds. The wide diffusion - particularly among artisans - of the Florentine debt, for example, during the revolt of the Ciompi prevented the government from reforming significantly the system of borrowing. ${ }^{34}$ The registers of the Genoese debt witnessed a significant increase of the number of bondholders, from 1,773 in 1392 to 11,315 in 1460 and a slight decline in 1500 with 9,997 nominees. ${ }^{35}$ One can argue that in the second half of the fifteenth century one fourth or one fifth of the urban population held credits of their

\footnotetext{
${ }^{29}$ See, for example, Julius Kirshner, 'Angelo degli Ubaldi and Bartolomeo da Saliceto on Priviliged Risk: Investments of Luchino Novello Visconti in the Public Debt of (Monte Comune) of Florence', Rivista internazionale di diritto comune, 14 (2003), pp. 83-117.

${ }^{30}$ Julius Kirshner, 'Papa Eugenio IV e il Monte Comune. Documenti su investimento e speculazione nel debito pubblico di Firenze’, Archivio Storico Italiano, 127 (1969), pp. 341-43, 344.

${ }^{31}$ Ibid., p. 352.

${ }^{32}$ Heinrich Sieveking, Studio sulle finanze genovesi nel medioevo e in particolare sulla Casa di S. Giorgio (Genova: Società Ligure di Storia Patria, 1906), vol. 2, p. 29.

${ }^{33}$ See, for Florence, Roberto Barducci, 'Politica e speculazione finanziaria a Firenze dopo la crisi del primo trecento (1343-1358)’, Archivio storico italiano, 137 (1979), p. 204.

${ }^{34}$ Gene Brucker, Dal comune alla signoria. La vita pubblica a Firenze nel primo rinascimento (Bologna: il Mulino, 1981), p. 61. By 1380 it seems that there were about 5,000 creditors. See also Renzo Ninci, 'La politica finanziaria della Repubblica fiorentina dopo il Tumulto dei Ciompi (13801425): Un tentativo di "Programmazione”?', in Renzo Ninci (ed.), La società fiorentina nel Basso medioevo: Per Elio Conti (Roma: Istituto Storico Italiano per il Medio Evo, 1995), pp. 151-167.

${ }^{35}$ Sieveking, Studio, vol. 1, pp. 205-6; Jacques Heers, Gênes au XVe siècle (Paris: Sevpen, 1961), p. 175. It is intesting to recall that the British loan of 1694, which gave life to the Bank of England, was underwritten by 1,268 people: P. G. M. Dickson, The financial revolution in England. A study in the development of public credit 1688-1756 (Aldershot: Gregg Revivals, 1993²), p. 254.
} 
commune. ${ }^{36}$ It must however be considered that if in the early phases the amount of subscribers increased, later it was to shrink. ${ }^{37}$ The picture provided by the Florentine catasto of 1427 is eloquent.

Table 3: The distribution of Monte credits in Florence in 1427

$\begin{array}{cc}\text { \% of huseholds } & \text { \% of Monte credits } \\ 100 & 100 \\ 99 & 56,97 \\ 98 & 42,91 \\ 97 & 35,34 \\ 96 & 30,22 \\ 95 & 25,42 \\ 90 & 13,85 \\ 80 & 5,71 \\ 70 & 2,18 \\ 60 & 0,91 \\ 50 & 0,3 \\ 40 & 0,07 \\ 30 & 0,01 \\ 20 & 0 \\ 10 & 0\end{array}$

Source: David Herlihy, 'Family and Property in Renaissance Florence', in David Herlihy, Cities and Society in Medieval Italy (London: Variorum, 1980), p. 8 of the essay xiii.

It is worth noting that in 1427 the Gini index of wealth concentration was 78.75, while that of Monte credits was 89.67. Still, data of the catasto of 1480 stress the close relation between wealth and Monte investments. ${ }^{38}$

Bonds were used in many ways, as the social base of citizens being involved in the system enlarged and the size of government indebtedness grew. Buying and selling was extremely important on the local credit market, favoring diffused speculative behaviors. These were behaviors that involved mainly medium and big creditors, whereas small bondholders tended to be quite passive. ${ }^{39}$ Credits were used to pay taxes, so as to allow governments to withdraw a share of the debt by means of taxes. Because in

\footnotetext{
${ }^{36}$ I have estimated the Genoese population in 1460 at 40,000 and in 1500 at 50,000: see Giuseppe Felloni, Scritti di storia economica (Genova: Società ligure di storia patria, 1999), vol. 2, pp. 11771215.

${ }^{37}$ Unfortunately, there are only a few works, mostly on Florence, on this crucial aspect. Sieveking, Studio, vol. 1, p. 57; and Bernardino Barbadoro, Le finanze della repubblica fiorentina. Imposta diretta e debito pubblico fino all'istituzione del Monte (Firenze: Olschki, 1929), pp. 652-54, had noticed this phenomenon. For recent analyses see: Anthony Molho, 'Créanciers de Florence en 1347. Un aperçu statistique du quartier de Santo Spirito', in La Toscane et les Toscans autour de la Renaissance. Cadre de vie, société, croyances. Mélanges offerts à Charles-M. de La Roncière (Aixen-Provence: Publications de l’Université de Provence, 1999), pp. 79-93.

38 Anthony Molho, Marriage alliance in late medieval Florence (Cambridge, Mass. : Harvard University Press, 1994), pp. 80 ff. Data refers to the Dowry Fund.

39 See Molho,'Créanciers de Florence', pp. 83, 88; Juilis Kirshner and Jacob Klerman, 'The sevenpercent fund of renaissance Florence', in Banchi pubblici, banchi private e monti di pietà nell'Europa preindustriale. Amministrazione, tecniche operative e ruoli economici (Genova: Società ligure di storia patria, 1991), p. 396. Is is likely that in Venice and Genoa the upward concentration was lower than in Florence.
} 
many cases tax farmers could pay a part of their lease through bonds and overdue interest, they helped to maintain the market lively ${ }^{40}$. Bonds, furthermore, were widely used as surrogate of cash, to buy goods, to form dowries and to provide guarantees for further loans. ${ }^{41}$

The return provided by state credits depended of course on both the capacity of governments to pay regularly interest charges and the general economic atmosphere. Between the late fourteenth and the early fifteenth century, governments proved ever and ever unable to maintain their promises. As difficulties turned out, market prices of bonds steadily declined, and the way to speculation was opened up.

Figure 1

Market prices of government bonds, 1285-1590

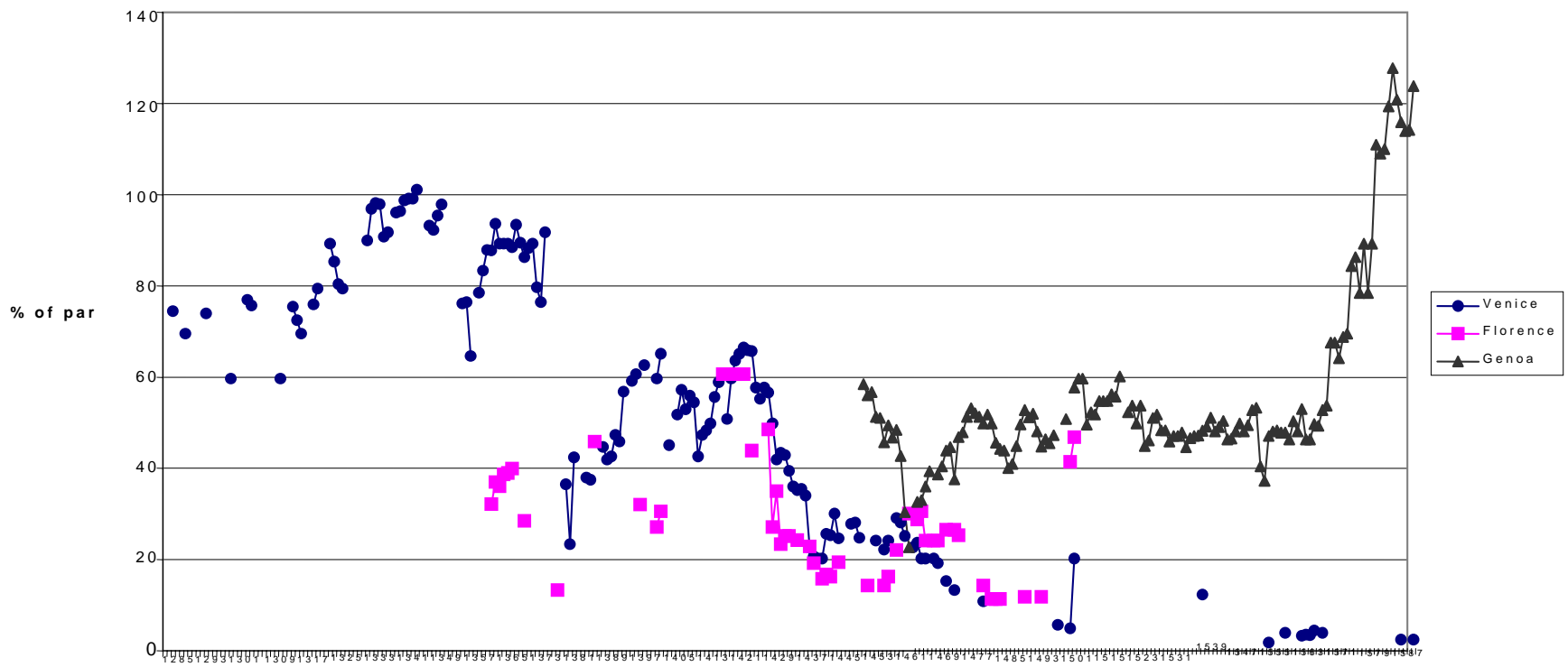

Source: Luciano Pezzolo, 'Bonds and government debt in Italian city states, 1250-1650', in Goetzman and Rouwenhorst (eds), Origins of Value, p 154.

The restless devaluation of securities, however, forced Florence and Venice to launch new series, which had the aim to renew the relationship between state and taxpayers, who had to get cash, possibly by selling their state credits, so as to pay for new obligatory loans.

\footnotetext{
${ }^{40}$ Sieveking, Studio sulle finanze, vol. 2, pp. 37-38; Marin Sanudo, Diari, ed. Rinaldo Fulin et alii, 58 vols (Venezia: Deputazione di storia patria, 1879-1903), vol 52, col. 302.

${ }^{41}$ Much information can be drawn from Florentine material. See, for some examples, Ugolino di Niccolò Martelli, Ricordanze dal 1433 al 1483, ed. Fulvio Pezzarossa (Roma: Ed. di storia e letteratura, 1989); Francesco di Matteo Castellani, Ricordanze, ed. Giovanni Ciappelli (Firenze: Olschki, 1992) vol. 1; Giovanni Chellini da San Miniato, Le ricordanze, ed. Maria Teresa Sillano (Milano: FrancoAngeli, 1984).
} 
The market witnessed remarkable variations according to the typology of bonds. If it is obvious that before the consolidation of the debt several credits were traded, characterized by the date of maturity and the taxes on which they relied, a relative heterogeneity persisted even after the unification of the series. In fifteenth-century Florence, along with the Monte commune bonds, were negotiated those of the Monte dei depositi (since the early century), those of the Monte di Pisa (since 1406), those of the Monte dei cinque interi (since 1424), those of the Monte dei Prestanzoni (since 1425), those of the Monte delle doti (since 1425) as well as those of the Monte comune nuovissimo (since 1446). ${ }^{42}$ In early sixteenth- century Venice, people could invest on bonds of the Monte vecchio, of the Monte nuovo (1482), of the Monte nuovissimo (1509), of the Monte sussidio (1526), and of the Depositi in zecca (since the 1520s). ${ }^{43}$ So the choice was very wide, although destined to reduce, for bonds tended to adjust around one interest rate. Nevertheless it is wondering whether such menu was a feature of a developed credit market. According to Larry Neal, a wide supply of bonds would restrain the development of financial markets, in that it would bring about a limited homogeneity of conditions. ${ }^{44}$ This would cause insufficient transparency and high transaction costs. In the Italian case, despite several issues, the market does not present a wide heterogeneity. Investors had a few choices and mostly linked to government credits. One could even argue that, within the context of both modest demand and restricted market, the position of the government was that of a monopsonist, with the attached advantages.

A peculiar aspect of market concerned the negotiability of overdue interest (the so-called paghe). Since claims upon paghe fell due, they were negotiable, as much as the state securities. From the mid-fifteenth century, the Genoese government used to pay interest charges after at least four years since their maturity; in the meanwhile, creditors' arrears were registered in special accounts of lire di paghe until they were paid. ${ }^{45}$ The creation of the lire di paghe, whose value progressively increased as the maturity date got closer, institutionalized the system of arrears. It was thus created a market, which counted annually as much as 10,000 transactions, ${ }^{46}$ based upon an intense speculation extremely sensitive to events. It is noteworthy that in 1506 a riot in Genoa was said to be provoked by shorters.

As far as credit market in principalities, it is not surprising that information is very scarce. As we have already seen, most of princes' indebtedness relied on financial means related to trade, whose negotiability at least up through the fifteenth century was socially limited. A partial

\footnotetext{
${ }^{42}$ See Elio Conti, L'imposta diretta a Firenze nel quattrocento (1427-1494) (Roma: Istituto Storico Italiano per il Medio Evo, 1984), pp. 30-31, 39, 128.

${ }^{43}$ Luciano Pezzolo, 'The Venetian government debt, 1350-1650', in Boone, Davids and Janssens (eds), Urban public debts, p. 62.

${ }^{44}$ Larry Neal, 'How it all began: the monetary and financial architecture of Europe during the first global capital markets, 1648-1815', Financial History Review, 7 (2000), pp. 117-40.

${ }^{45}$ Heers, Gênes, pp. 163 ff., 260-63; José-Gentil da Silva, 'Le sconto à Gênes. A propos d'un croquis', Annales, 13 (1958), pp. 150-53; and Julius Kirshner, 'The Moral Problem of Discounting Genoese Paghe, 1450-1550’, Archivum Fratrum Praedicatorum, 47 (1977), pp. 109-67.

${ }^{46}$ Heers, Gênes, p. 166.
} 
exception is represented by Roman vacable offices, which were to some extent traded.

Buying and selling credits was generally made before a notary or a scribe of the office managing the debt, and registered on the books of the same office. Transaction costs were quite modest and of course were lower depending on the amount negotiated. In Genoa the shares (luoghi) sold were taxed with 20 soldi each, split equally between the buyer and the seller. To taxes one has to add the intermediation costs. Some operations of Paolo Guinigi, lord of Lucca from 1400 to 1430, on the Venetian market provide a good picture of the costs. The total of transaction costs proved to be $1.5 \%$ of the total amount, but most of the expenses were due to bills of exchange in order to get cash. ${ }^{47}$ It is interesting to compare this percentage with those relating to other dealings. During the second half of the fourteenth century, only the tax on selling land in Florence withdrew 5\%. Toward the midfifteenth century, in Siena a similar tax was 3.3-3.5\% of the declared value; while one had to pay on dowries $1.5 \%$ of the total amount. ${ }^{48}$ In the $1760 \mathrm{~s}$, on the highly developed financial market of Amsterdam brokering costs accounted for $0.25 \%$ of the nominal value of obligations. ${ }^{49}$ Such a comparison shows that state credits trading in Italy did not thus present high transaction costs, as a proof of the efficiency of the financial market. The role of middlemen (sensali) was crucial: intermediaries between demand and supply, they fixed the price according to news that diffused throughout a marked that presumably was restricted. In Venice everything occurred within an area circumscribed between Rialto, the financial heart of the city, and San Marco square. It is nonetheless worth stressing that the big limit of the Italian market - as elsewhere - was due to the fact that there were not bearer bonds. ${ }^{50}$ There were actually several difficulties, both legal and practical, to protect the last creditor in case of default of his own debtor. A true large-scale innovation emerged during the second half of the sixteenth century in Antwerp, where in the local stock exchange several securities were negotiated, among which state bonds. ${ }^{51}$ The negotiability, however, of state bonds was allowed in Holland only beginning from the midseventeenth century. ${ }^{52}$ In a restricted market such as the urban one, evidently, the transfer of bearer bond was not an urgent need. Governments

\footnotetext{
${ }^{47}$ See data in Reinhold Mueller, 'Foreign Investment in Venetian Government Bonds and the Case of Paolo Guinigi, Lord of Lucca, Early Fifteenth Century', in Herman Diederiks and David Reeder (eds), Cities of finance (Amsterdam: Koninklijke Nederlandse Akademie van Wetenschappen, 1996), p. 82.

48 Il libro di ricordanze dei Corsini (1362-1457), ed. by Armando Petrucci, (Roma: Istituto Storico Italiano per il Medio Evo, 1965), pp. 7-8, 62, 113; Balestracci, La zappa, p. 143.

${ }^{49}$ Oscar Gelderblom and Joost Jonker, 'Probing a Virtual Market. Interest Rates and the Trade in Government Bonds in the Dutch Republic', paper presented at the seminar on The Origins and Development of Financial Markets and Institutions, Urbana (Ill.), April 27-29, 2006, p. 20. See also Wantije Fritschy, ‘A “Financial Revolution” Reconsidered: Public Finance in Holland During the Dutch Revolt, 1568-1648’, Economic History Review, 56 (2003), p. 64.

${ }^{50}$ Some examples in John Munro, 'The Medieval Origins of the Financial Revolution: Usury, Rentes, and Negotiability', International History Review, 25 (2003), pp. 505-615.

${ }^{51}$ Ibid.; Hermann van der Wee, The Low Countries in the early modern world (Aldershot: Variorum, 1993), pp. $145 \mathrm{ff}$.

${ }^{52}$ Gelderblom and Jonker, 'Probing a virtual market'.
} 
were concerned more with identifying and finding the effective bondholders than allowing a full and uncontrolled portability.

\section{Credible commitments?}

The forced loans system de facto circumvented a crucial point, namely the need of robust constraints that compelled governments to fulfill their creditors. It is therefore inopportune to define such a system as a true public debt because, among other things, the voluntary character of investment was lacking. ${ }^{53}$ For foreign investors instead the picture is different. Their investments were voluntary and their amount reflected on the one hand the degree of reliability governments enjoyed in markets and on the other the capability of ensuring high returns to investors on the secondary market.

As far as citizens are concerned, the announcement that given tax receipts were earmarked to paying interest represented an important element, even if not crucial. Credibility probably depended on both government's reputation and, above all, the heavy involvement of the ruling group as state creditors. It was the case of Venice, where several members of the patriciate held wide shares of debt. ${ }^{54}$ Genoese investors relied on guarantees much more effectively than elsewhere. Beginning from 1407 the foundation of the Casa di San Giorgio - that is a consortium of creditors of the government - allowed a close control over state finance and debt management. This semi-private institution played a central role in state financing, heavily influencing the government's policy. The collaboration between the powerful representatives of the Casa and the government provides a excellent example of how the whole power of proxy to the Casa for managing the state finance allowed the commune to collect enormous amounts of money at low cost. The same principle (the responsibility of a group in creditors for paying their interest from tax receipts) will be found in sixteenth-century Rome and, with much more modest results, in Francis I’s Paris. ${ }^{55}$

The key feature that underpinned the system and above all supported a vivid and large market - which in turn called for a certain degree of credibility - laid in the close permeation between major bondholders and power elite. As long as this identity subsisted it would have been unlikely the government defaulted. The success and efficiency of government debt in the Italian city-states would not be as much the natural outcome of the republican institutional structure (as opposed to princely states) as the result of a power system that took advantage from the mechanism of state indebtedness in a rather limited context. If this hypothesis is plausible, it is

\footnotetext{
${ }^{53}$ Pezzolo, The Venetian government debt, p. 67. The coercive character of Genoese loans, however, is not always evident.

${ }^{54}$ Unfortunately quantitative data are lacking, but it suffices to look through Gino Luzzatto's, 'Introduzione' to I prestiti, and Mueller, The Venetian money market, to get some evidence.

${ }^{55}$ For a comparison between the two systems, Luciano Pezzolo, 'Government Debts and Trust. French Kings and Roman Popes as Borrowers, 1520-1660’, Rivista di Storia Economica, 15 (1999), pp. 233-61. A revaluation of the royal bonds is put forward by Mathilde Moulin, 'Les rentes sur l’hôtel de ville de Paris sous Louis XIV’, Histoire, Economie, Société, 17 (1998), pp. 623-48.
} 
then necessary to reconsider the classic model put forward by North and Weingast. ${ }^{56}$

It is well known that the two scholars argued a close relation between the institutional dynamics in early eighteenth-century England and the emergence of a modern and advanced financial market. In short, as the parliament took on the whole political power after the Glorious Revolution the road would have paved to funding the debt, with the resulting decline of interest rate and development of the financial market. All that was due to the credibility of the parliament as a debtor and above all as unique responsible of fiscal policy as well as a more effective enforcement of property rights. The thesis of North and Weingast had a large impact and prompted to put institutions, the financial sector and the legal context at the heart of the debate on the economic development. ${ }^{57}$ Recent critics, however, have stressed that the Glorious Revolution did not represent a turning point concerning property rights nor determined a such dramatic change in the trend of interest rate. ${ }^{58}$ It was furthermore argued that interest rate variations show on the contrary a significant relation with the turnover of parties (Tory and Whig) in power. ${ }^{59}$ The link between efficiency of public debt and constitutional power would therefore seem quite weak. It would instead be important to look at the fiscal system: it seems in fact that there is a positive relation between the width of representative institutions and tax efficiency. ${ }^{60}$ Some scholars argue that the power of the English state laid first of all in its capability to borrow thanks to its tax resources. Likewise a similar model has been put forward for Holland. ${ }^{61}$ Let us try to apply, though briefly, this hypothesis to the Italian case.

In order to compare the different cases interest rates will be examined, which can after due consideration be considered as 'the most evident quantitative dimension of the efficiency of the institutional framework' ${ }^{62}$ It is manifest that republican governments paid for loans less

\footnotetext{
56 Douglass C. North, Barry R. Weigast, 'Constitutions and Commitment: the Evolution of Institutions Governing Public Choice in Seventeenth-Century England', Journal of Economic History, 49 (1989), pp. 803-32.

57 Rafael La Porta, Florencio Lopez de Silanes, Andrei Shleifer and Robert Vishny, 'Legal Determinants of External Finance', Journal of Finance, 52 (1997), pp. 1131-50.

${ }^{58}$ Gregory Clark, 'The Political Foundations of Modern Economic Growth: Britain, 1540-1800, Journal of Interdisciplinary History, 26 (1996), pp. 563-88; Nathan Sussman and Yishay Yafeh, Constitutions and Commitment: Evidence on the Relation Between Institutions and the Cost of Capital, Cepr Discussion Paper, n. 4404, June 2004.

59 David Stasavage, Public Debt and the Birth of the Democratic State. France and Great Britain, 1688-1789 (Cambridge: Cambridge University Press, 2003), pp. 68 ff.; but see also Bruce G. Carruthers, Politics and Markets in the English Financial Revolution (Princeton: Princeton University Press, 1996); Avinash Dixit and John Londregan, 'Political Power and the Credibility of Government Debt', Journal of Economic Theory, 94 (2000), pp. 80-105.

${ }^{60}$ Philip T. Hoffman and Kathryn Norberg (eds), Fiscal crises, liberty, and representative governments 1450-1789 (Stanford: Stanford University Press, 1994).

${ }^{61}$ John Brewer, The Sinews of Power. War, Money and the English State, 1688-1783 (New York: Knopf, 1989); Patrick K. O’Brien, 'The Political Economy of British Taxation, 1660-1815', Economic History Review, 41 (1988), pp. 1-32; Fritschy, 'A “Financial Revolution”, pp. 57-89.

${ }^{62}$ Douglass C. North, Institutions, institutional change and economic performance (Cambridge: Cambridge University Press, 1990), p. 69.
} 
than kings and princes. It is necessary to ask why. ${ }^{63}$ First of all, lords look to be scarcely reliable debtors and consequently they have to pay a high-risk premium. Monarchs did not actually present credible commitments to lenders. The only risk was due to the eventual bad reputation that had been forming over the past. It is not simple to compare interest paid by republics with that of principalities'. Market conditions were different. Princes, on the one hand, negotiated loans according to certain elements (power relations, patronage, guarantees, capital availability), republics on the other hand resorted mainly to forced loans, at lower interest than that of market. It is therefore necessary to examine voluntary loans raised by republican governments. When Florence's treasury needed cash it resorted to professional financiers' services. In the Arno city bankers were, as it is well known, not short and it is not surprising to find them within the mechanism of state financing. ${ }^{64}$ But that means that public borrowing was dear, and sometimes dearer than in the private market. Some data, although scanty, are worth being considered.

Figure 2

Interest rates in Florence, 1290-1380

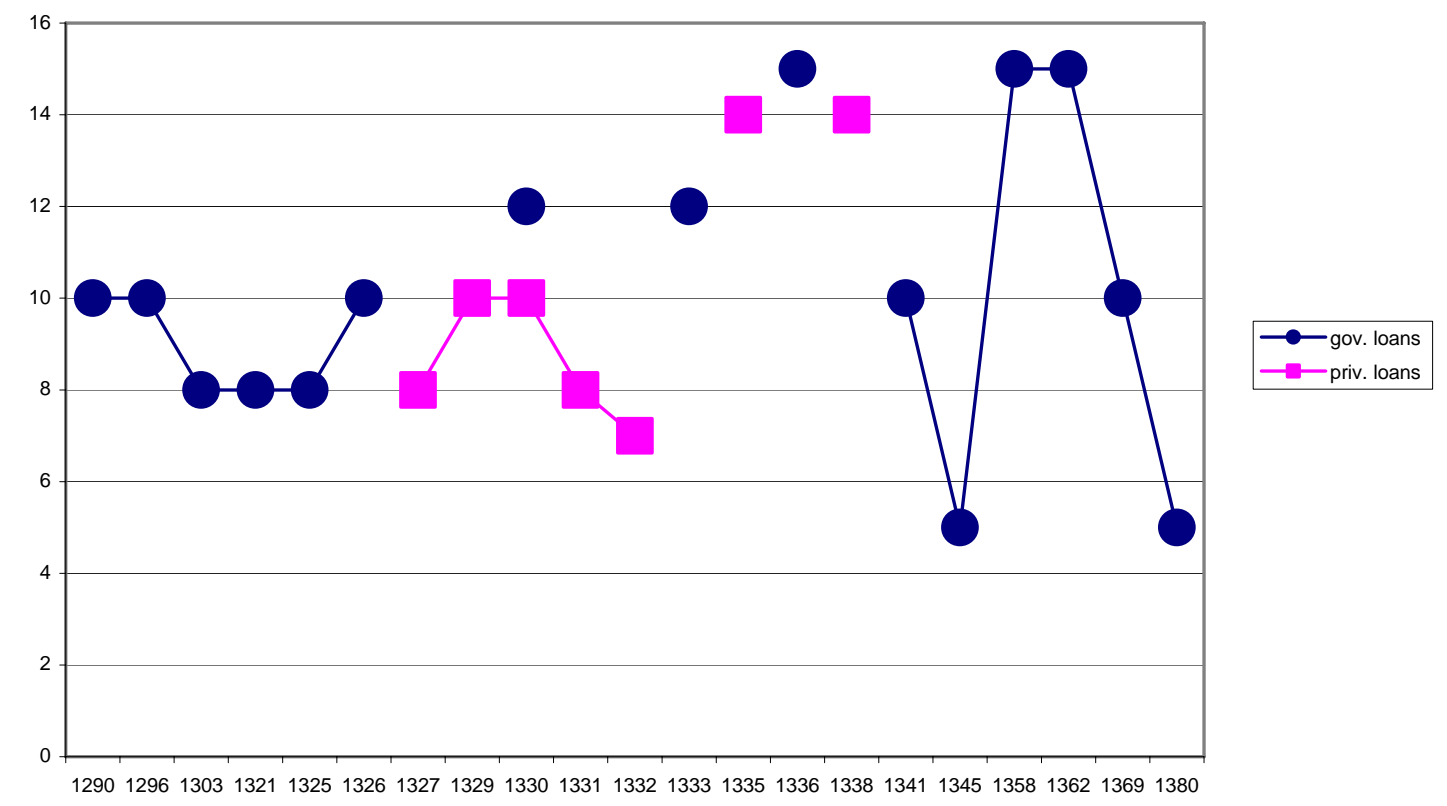

Sources: Barbadoro, Le finanze della repubblica, pp. 534 sgg.; Armando Sapori, Studi di storia economica, 3rd edn (Firenze: Sansoni, 1982), vol. 1, p. 197. Interest rates are on medium and long term loans.

Of course one has to consider that high government rates correspond to periods of severe need, due to political and military factors. Let us, however, make some consideration, albeit forcibly provisional. The

${ }^{63}$ See the data published by Stephan R. Epstein, Freedom and Growth. The Rise of States and Markets in Europe, 1300-1750 (London: Routledge, 2000), pp. 20-23; and the discussion of David Stasavage, 'Cities, Constitutions, and Sovereign Borrowing in Europe, 1274-1785', mimeo 2005.

${ }^{64}$ Molho, Florentine public finances, p. 164. 
consolidation of the mid-1340s did not provide great relief to communal coffers. In the 1350s and 1360s the high interest rate promised (a nominal $5 \%$ on a nominal principal twice or three times as much that effectively paid) shows how it was hard to collect money from voluntary lenders. The spread however, which could be considered as the risk premium paid by the government, was not usually large. This meant that a certain confidence, difficulties notwithstanding, was widespread among investors. It cannot be denied that in Florence money was largely diffused and that sophisticated financial techniques and skill helped maintain the money cost quite moderate. A further element worth stressing concerns the interest rate trend. In this case it seems that government interest rate had driven the market movement, increasing also those among individuals. It remains to account for the influence of declining government yield on private credit market. ${ }^{65}$

It is worth stressing a further crucial element. Beginning from the midfourteenth century, tax pressure increased, just as the funded debt system was created and the aggressive expansion of the Florentine state took place. The growth of indebtedness was actually backed by tax receipts: both sustained each other to provide the commune with resources necessary to political expansion and needed to fulfill creditors' interest. ${ }^{66}$

\section{Conclusions}

In late-medieval Western Europe some differences turned out, characterizing the system of indebtedness of urban communities. There were, on the one hand, Mediterranean cities, which resorted to forced loans mainly through fiscal records and, on the other hand, there were cities in northern France and Flanders that since the thirteenth century sold annuities to finance their deficit. These annuities were bought also in other markets and had the character of life annuities. ${ }^{67}$ It is worth stressing this element. In northern Europe, from France to Switzerland, life annuities enjoyed large success, at least up to the early sixteenth century, but in Italy they were not widely used. It is very likely that Italian governments were aware of such financial devices: several merchants acted in French and Flemish cities and so it would be easier to get information. Issuing annuities was not a mere trifle. In order to take profit, the government had to exploit statistical and actuarial knowledge, which were not simple and were to develop starting from the seventeenth century. ${ }^{68}$ The advantage that these annuities were

\footnotetext{
${ }^{65}$ Bruno Dini, Manifattura, commercio e banca nella Firenze medievale (Firenze: Nardini, 2001), p. 94, argues that Monte loans had a pegging effect on private market.

${ }^{66}$ Marvin B. Becker 'Economic Change and the Emerging Florentine Territorial State', Studies in the Renaissance, 13 (1966), pp. 7-39; Id., 'Problemi della finanza pubblica fiorentina nella seconda metà del Trecento e nei primi del Quattrocento’, Archivio Storico Italiano, 123 (1965), pp. 433-66.

67 James D. Tracy, 'On the Dual Origins of Long-Term Urban Debt in Medieval Europe', in Boone, Davids and Janssens (eds), Urban public debts, pp. 13-24.

68 James M. Poterba, 'Annuities in Early Modern Europe', in William Goetzman and Geert Rouwenhorst (eds), Origins of Value. Financial Innovations in History (New York: Oxford University Press, 2005), pp. 207-24. But in the period 1397-1402 some Burgundian cities issued life annuities at interest rates linked to the age of investors: Wim P. Blockmans, 'Le crédit public dans les
} 
self-liquidating was not probably offset by the great uncertainty stirring over life annuities. By the late fifteenth and particularly the early sixteenth century, some Italian governments begun to issue life annuities, maybe because of their severe financial needs. In some cases it was these very annuities that paved the way to a true primary state bonds market, as in Rome and Venice.

After all one can argue that the indebtedness mechanisms of western Mediterranean cities were not very different. Loans issued by Valencia or Barcelona had much in common with Florentine or Venetian loans. Rather, in the Aragonese territories it appears missing the character strongly forcible, which instead is to be found in Italy. In the Peninsula, lending to governments is not as much an investment choice as a duty of taxpayers. Accordingly, the problem of credibility of institutions did not play a significant role. It would however be wrong to deny some innovations that had been occurring in northern Italy, namely the emergence of a vivid secondary market of state bonds. The turn over of bonds was quite fast, arguing an annual rate of change of $5 \%$ of the nominal amount. ${ }^{69}$ The secondary market allowed to liquidate credits in case of need; furthermore it offered attractive chances of speculation on both bonds themselves and overdue interest. These speculations nevertheless did not seem to characterize the practice in the main Italian market - with the exception of Genoa - due to the tiny size of commercial credit and the conservative behavior of bondholders. ${ }^{70}$ The presence of state credits became ever and ever consistent in the assets of noble families and of religious and charity institutions. These were categories that by definition do not follow speculative behaviors. A dynamic secondary market was the product of at least two elements: on the one hand, creditors-taxpayers, and particularly the less well-off, were compelled to sell their credits to face the government's growing demand for further loans and, on the other hand, buyers were attracted by the high profitability of credits and the belief that the government would keep its promises. The credibility of government institutions therefore dealt with speculators in the secondary market. But who were they, if not the members themselves of the ruling groups?

\footnotetext{
Pays-Bas méridionaux au bas moyen âge', in Henri Dubois (ed.), Local and international credit in the middle ages and the 16th century (Bern: Ninth International Economic History Congress, 1986), p. 4.

69 Pezzolo, 'Bonds and Government Debt in Italian City States, 1250-1650', in Goetzman and G. Rouwenhorst (eds), Origins of Value, p. 156.

${ }^{70}$ Oscar Gelderblom and Joost Jonker, 'Amsterdam as the Cradle of Modern Futures and Options Trading, 1550-1650', ibid., p. 194.
} 